\title{
Impact of enzyme replacement therapy on survival in adults with Pompe disease
}

\author{
Deniz Güngör ${ }^{1 *}$, Michelle Kruijshaarr ${ }^{1}$, Iris Plug ${ }^{1}$, Ralph D'Agostino Sr. $^{3}$, Marloes Hagemans ${ }^{1}$, Arnold Reuser ${ }^{2}$, \\ Ans van der Ploeg ${ }^{1}$
}

From Proceedings of the 6th European Symposium: Steps Forward in Pompe Disease Berlin, Germany. 23-24 November 2012

\section{Background}

Since 2006, enzyme replacement therapy (ERT) has been available as a treatment for patients with Pompe disease. ERT has shown efficacy concerning muscle strength and pulmonary function in adult patients. However, no data on the effect of ERT on the survival of adult patients are currently available. Our objective was to assess the effect of ERT on survival in adult patients with Pompe disease.

\section{Methods}

Data were collected as part of an international observational study conducted between 2002 and 2011 in which patients were followed on an annual basis. Time dependent covariate Cox's proportional hazards models were used for univariate and multivariate analyses of the risk of death. Patients who discontinued treatment were censored at the time of discontinuation. Additionally, we used an 'intention to treat' approach.

\section{Results}

Overall, 283 adult patients with a median age of 48 years (range, 19-81 years) were included in the study. Seventytwo percent of the patients started ERT at some time during follow-up and 28\% never received ERT. During follow-up (median, 6 years; range, 0.04 to 9 years), 46 patients died, 28 (61\%) of whom had never received ERT. After adjustment for age, gender, country of residence, and disease severity (based on wheelchair and ventilator use), ERT was positively associated with survival (hazard ratio 0.41, CI 95 \% 0.19-0.87). The hazard ratio for ERT in the multivariable analyses of the intention to treat approach was 0.33 (CI $95 \%$ 0.15-0.73).

${ }^{1}$ Department of Pediatrics, Center for Lysosomal and Metabolic Diseases, Erasmus MC University Medical Center, Rotterdam, The Netherlands Full list of author information is available at the end of the article

\section{Conclusion}

Our prospective study provides novel data on the positive effect that ERT has on survival in adults with Pompe disease. Given the fact that ERT was only registered in 2006, this may be considered as a very promising finding.

\section{Author details \\ 'Department of Pediatrics, Center for Lysosomal and Metabolic Diseases, Erasmus MC University Medical Center, Rotterdam, The Netherlands. ${ }^{2}$ Department of Clinical Genetics, Center for Lysosomal and Metabolic Diseases, Erasmus MC University Medical Center, Rotterdam, The Netherlands. ${ }^{3}$ Department of Mathematics and Statistics, Boston University, Harvard Clinical Research Institute, Boston, MA, USA.}

Published: 29 May 2013

doi:10.1186/1471-2474-14-S2-P15

Cite this article as: Güngör et al: Impact of enzyme replacement therapy on survival in adults with Pompe disease. BMC Musculoskeletal Disorders 2013 14(Suppl 2):P15.

Submit your next manuscript to BioMed Central and take full advantage of:

- Convenient online submission

- Thorough peer review

- No space constraints or color figure charges

- Immediate publication on acceptance

- Inclusion in PubMed, CAS, Scopus and Google Scholar

- Research which is freely available for redistribution 